\title{
Building A Community of Inquiry (CoI) Through the Implementation of Lesson Study in Higher Education Level
}

\author{
Taufik Ikhsan Slamet \\ State University of Malang, Indonesia \\ taufik.ikhsan.tep@um.ac.id
}

\author{
Ahmad Supriyanto \\ State University of Malang, Indonesia \\ ahmad.supriyanto.fip@um.ac.id
}

\begin{abstract}
This article describes the implementation of lesson study in the higher education context. It aims to pioneering lesson study as a part of professional development training for lecturers in any discipline. We document four lesson study activities which consist three cycles for each activity, and describe changes occurred along the process, especially in the phase of the plan, do, and see the step. Unlike the intended subjects of lesson study, the topics delivered in the activities are commonly from social science and humanities. The characteristics of the subjects eventually provide greater opportunities to attempt a various form of instructional approaches. Therefore, it is highly recommended for all higher education institution to implement and monitor the progress of lesson study professionally, based on the characteristic of the students and environment.
\end{abstract}

Keywords: professional development, collaborative work, community of inquiry, learning, and teaching

\section{INTRODUCTION}

Today, many would agree with the idea that grounding professional development in actual classroom practice is a highly powerful means of fostering effective teachers (Lieberman, 1996; Fernandez, 2002). In recent years, however, there have been discussions about the need to improve university teachers' pedagogical thinking and skills as well. As a consequence, training of university teachers has recently become a widespread trend in many countries (Postareff et. al., 2007). Many believe that teaching is related to students' learning approaches and succeedingly to their learning outcomes.

Teacher development program has been an increasing issue and trend in recent years around the countries. Many governments focus their education priority for improving teaching competencies for teachers, particularly in conducting technology into a learning process. Since this priority has been taken into account, we also have to be aware of how teaching development program in higher education level is carried out. Because, many countries, such as Norway, UK, and Sri Lanka have made decisions about the compulsory pedagogical training of university teachers (Gibbs \& Coffey, 2004).

A research by Bailey (1999) was a trigger for higher education institution to consider pedagogical training as a prominence for lecturers. The research found that gaining higher qualification increased academics' motivation and self-efficacy for doing research, but not with the teaching. Since the accreditated institution variables require lecturers in higher education institution to hold a master degree in minimum, this requirement perhaps abandon the most fundamental skill that must be mastered by all lecturers, that is teaching. One proper example has been provided by a research from Postareff et. al. (2007). They found that lecturer faced some pressure for research productivity because every lecturer at the University of Helsinki is expected to do research. This might have an effect on how much to invest in developing teaching practices.

The UK Government have committed to provide the best solution in carrying lecturer development program in teaching. The program entitled Quality of Learning and Teaching in Higher Education has been delivered in several institutions around the UK. This program was about "improving outcomes for students, and indirectly for their employers, and for society and the economy" (TQEC, 2003). This program also was to provide a reliable means to assure stakeholders of the commitment of staff and institutions to providing an inspirational, challenging, transferrable, and enjoyable learning experience to all higher education institution (UUK, 2004). Deciding the program as a compulsory training prudence was a successful policy both for the UK and elsewhere because making educational development courses like these compulsory will eventually lead to better teachers using a range of methods to develop the competencies of a new type of student for a postindustrial society (Trowler \& Bamber, 2005).

One of the promising strategies facilitating pedagogy training and teaching development is lesson study, which originally comes from Japanese education system. The expression lesson study is a literal translation for the Japanese word Jugyokenkyu-jugyo means lesson and kenkyu mean study or research. This translation can be misleading in the sense that lesson study is more than the study of lessons; it is rather a systematic inquiry into teaching practice much more broadly defined, which happens to be carried out by examining lessons (Fernandez, 2002). This strategy has also been introduced in South-East Asian countries such as Indonesia and Malaysia (see, for example, White \& Lim, 2008), as well as South America, South Africa (Ono \& Ferreira, 2010), and Australia (for example, Hollingsworth \& Oliver, 2005). In fact, Japanese mathematics instruction has transformed from teacher-directed instruction to child-centered instruction during the past fifteen years (Lewis and Tsuchida 1998; Yoshida 1999). The ability to make this change has widely been attributed to the efforts of lesson study (Takashi \& Yoshida, 2004).

Lesson study in higher education level is now growing rapidly in Indonesia, particularly in teacher education institution. All the lecturers in Indonesia are required to complete a basic training of instruction, 
entitled PEKERTI (Pelatihan Keterampilan Dasar Teknik Instruksional). Several universities and colleges have conducted lesson study as the final assignment of the training. It is assumed that the lesson study is the beginning of the professional lecturer development program. The aim of this professional development session is as like as what Pasley \& Weiss (2006) have stated, that is the professional development program is designed to deepen content knowledge and support teachers' content needs during implementation.

There are a number of reasons why Lesson Study offers the potential for sustained professional development. It offers teachers the opportunity to develop professional communities of inquiry, with ownership of the improvement effort, a commitment to inquiry, shared goals, and a sense of responsibility to their colleagues and students (Lewis et al., 2009). While progress is often slow at the start, the process can evolve over time with teachers beginning by weaving some of the simpler components of lesson study in with their existing practices, and only later the significance of other ideas such as developing a lesson rationale and documenting their own learning (Perry \& Lewis, 2009, p. 388).

This article describes how The State University of Malang, Indonesia, improves the lecturer's pedagogy skills through a compulsory training program called PEKERTI, which consists in-site training lecture, workshop, intensive guidance, and lesson study activities. The main focus of this paper is a brief explanation about the implementation of lesson study activities performed in the faculty of education, state university of Malang, by four junior lecturers of the faculty, who also were the participants of the PEKERTI program 2016. The activities were held in a semester at the end of 2016-2017 academic years based on the lesson study cycle from Asgher, including plan, do, see, and reflection.

\section{METHODS}

The lesson study approach is a method of professional development that encourages teachers to reflect on their teaching practice through a cyclical process of collaborative lesson planning, lesson observation, and examination of student learning (Anfara, 2009). Lesson study is a translation of the Japanese words jugyou (instruction, lessons, or lesson) and kenkyuu (research or study). The term jugyou kenkyuu encompasses a large family of instructional improvement strategies, the shared feature of which is observation of live classroom lessons by a group of teachers who collect data on teaching and learning and collaboratively analyze it (Lewis, 2002a, 2002b; Lewis \& Tsuchida, 1997, 1998; Wang-Iverson \& Yoshida, 2005; Lewis et. al., 2006).

Based on lesson study cycle formulated by Lewis (Takashi \& Yoshida, 2004), during the activities, the group members of lesson study Faculty of Education, State University of Malang (UM), work collaboratively to: (1) formulate long-term goals for student learning and development; (2) plan, conduct, and observe a "research lesson" designed to bring these long-term goals to life; (3) carefully observe student learning, engagement, and behavior during the lesson; and (4) discuss and revise the lesson and the approach to instruction based on these observations.

The lesson study approach conducted in the faculty of education is a way for lecturers to engage in professional development leading to activities that promote instructional change. The rational method on the cycle requires lecturers to set goals, discuss strategies, formulate activities, predict outcomes, implement the plan, assess students learning achievements, and evaluate the effectiveness of reaching those goals. A brief graph below depicts a comprehensive approach to the examined lesson study and states goals of the each step (Figure 1).

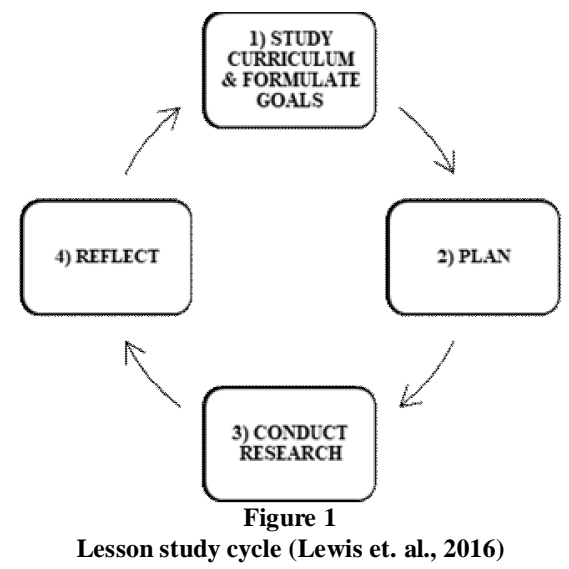

Consider long-term goals for student learning and development; and Study curriculum and standards, identify topic of interest. Select or revise research lesson write instruction plan that includes: (1) longterm goals; (2) anticipated student thinking; (3) data collection plan; (4) model of learning trajectory; and (5) rationale for chosen approach. One team member conducts research lesson, others observe and collect data. Formal lesson colloquium in which observers: (1) share data from a lesson; and (2) use the data to illuminate student learning, disciplinary content, lesson and unit design, and broader issues in teachinglearning. Documentation of cycle, to consolidate and carry forward learnings, new questions into next cycle of lesson study.

The cycle gives the group members the opportunities to: (1) make sense of educational ideas within their practice; (2) change the perspectives about teaching and learning; and (3) learn to see the practice from the student's perspective, and 4) Enjoy collaborative support among colleagues (Takashi \& Yoshida, 2004). Another important characteristic of lesson study is that it has played a significant role in improving curricula, textbooks, and teaching and learning materials. According to the previous colleague's experiences in the institution, the cycle can be flexible and adapted to the schedules of the group members. The group member, at the first time, discussed, examined, and justified the proper model of lesson study. And as a result, the cycle from Lewis was considered as the most suitable model for the faculties. 
The members of the lesson study group consist of four junior lecturers, who are from different department across discipline, in the faculty of education UM. As a controlling process, one of the senior lecturers is responsible as a supervisor of the lesson study activities. The tables below will show the group members and the chapter lesson which is chosen as a teaching subject (Table 1).

Table 1

Faculty of Education Lesson Study Members

\begin{tabular}{clll}
\hline No. & \multicolumn{1}{c}{ Name } & \multicolumn{1}{c}{ Department } & \multicolumn{1}{c}{ Subject Course } \\
\hline 1 & Taufik Ikhsan Slamet & Educational Technology Dept. & Evaluation and Assessment \\
2 & Evania Yafie & Preschool Education Dept. & $\begin{array}{l}\text { Game development in preschool } \\
\text { education }\end{array}$ \\
& & Primary Education Dept. & Basic Mathematics \\
4 & Ni Luh Sakinah & Indonesia literature \\
\hline Supervisor: Dr. Ahmad Supriyanto, M.Pd., M.M. & \\
\hline
\end{tabular}

Each member delivered four topics of the subject teaching, which each topic involved three phase of lesson study (plan, do, and see/reflect). For a single cycle, the group members were divided into two main roles in lesson study, which were a model and observers. A member who presented the plan was called a model, the others who were positioned to see the response of the students were called peers and observers. The supervisor, in this case, was also charged as the main observer, who was responsible to advise the plan, monitor the instruction, and guide in the reflection phase. Every member was required to bring four demonstrations as a model, and twelve roles as an observer.

Based on the syllabus of evaluation and assessment course, the chapters which were selected as the object of practices are previewed on the following Table 2.

Table 2

Summary of Topics on Lesson Study

\begin{tabular}{cllc}
\hline No. & \multicolumn{1}{c}{ Objectives } & \multicolumn{1}{c}{ Topics } & Order \\
\hline 1 & Classify the concepts of measurement, assessment, evaluation, test, and non-test & Basic concept of evaluation & 1 \\
2 & Identify taxonomy of learning objectives & Taxonomy of learning objectives & 2 \\
3 & Conduct need assessment in learning & Training needs analysis & 3 \\
4 & Identify norm and criterion based evaluation & Norm and criterion based evaluation & 4 \\
\hline
\end{tabular}

The topics and objectives above were generated based on the process of curriculum study and goals formulation, which also was resulted by the discussion among the model and the peers. The challenge in this process was that the model needed to adjust the schedule of every week topics to be proper with the curriculum of the subject. The challenge was due to this lesson study program was coincided with the beginning of the semester, which caused the model needed to choose the topics based on the syllabus of the course.

\section{RESULT}

The lesson study in the faculty of education was started from action plan to sharing experience process, which consisted three main steps as mentioned above (plan, do, see).

\section{Lesson Study 1 (LS 1)}

Table 3

Summary of Plan LS 1

\begin{tabular}{|c|c|c|c|c|}
\hline \\
\hline Model & : & Taufik I. Slamet & Topic & Basic concept of evaluation \\
\hline Peers & $:$ & $\begin{array}{l}\text { Evania Yafie (EY) } \\
\text { Ferril I. M. (FI) } \\
\text { Ni Luh S. N. (NS) } \\
\end{array}$ & Objective & $\begin{array}{l}\text { Classify the concepts of } \\
\text { measurement, assessment, } \\
\text { evaluation, test, and non-test }\end{array}$ \\
\hline Date and Place & : & $\begin{array}{l}\text { Friday, August } 26,2016 . \text { The } \\
\text { d2 building, Campus } 1 \text { UM. }\end{array}$ & Model of teaching & $\begin{array}{l}\text { Direct instruction (lecturing and } \\
\text { discussion) }\end{array}$ \\
\hline Suggestion & & \multicolumn{3}{|c|}{$\begin{array}{l}\text { Observer } 1 \text { (EY) } \\
\text { Time allocated for the instruction was considered not adequate based on a number of concepts } \\
\text { and activities delivered. } \\
\text { Observer } 2 \text { (FI) } \\
\text { It would be more proper if some activities were delivered in direct learning. } \\
\text { Observer } 3 \text { (NS) } \\
\text { The perception given in the beginning of instruction was less relevant to the main topics. }\end{array}$} \\
\hline
\end{tabular}

Do

37 students participated in the do process, held on 1 September 2017 at the D1 building of faculty of education UM. The objective was "students are able to Classify the concepts of measurement, assessment, evaluation, test, and non-test", which was delivered on the topic "basic concept of evaluation". The instruction was carried within two hours, with direct learning was selected as the approach of learning strategy. The model in this activity had arranged some materials delivered in power point slides and printed paper worksheet. In the end of instruction, the model 
delivered an assessment technique, called 'siapa berani' quiz. The quiz consisted 20 objective questions, which delivered on power point slide each question. The students needed to raise an answer as soon as the question displayed, and the answer was written in a small piece of paper but visible to the model. The students who had the right answer were able to continue in the quiz, and the students who had the wrong answer were asked to leave the chairs and stand in the front of the class. This quiz activity was observed as a useful method to drive positively students motivation to compete.

\section{See}

Table 4

Summary of See LS 1

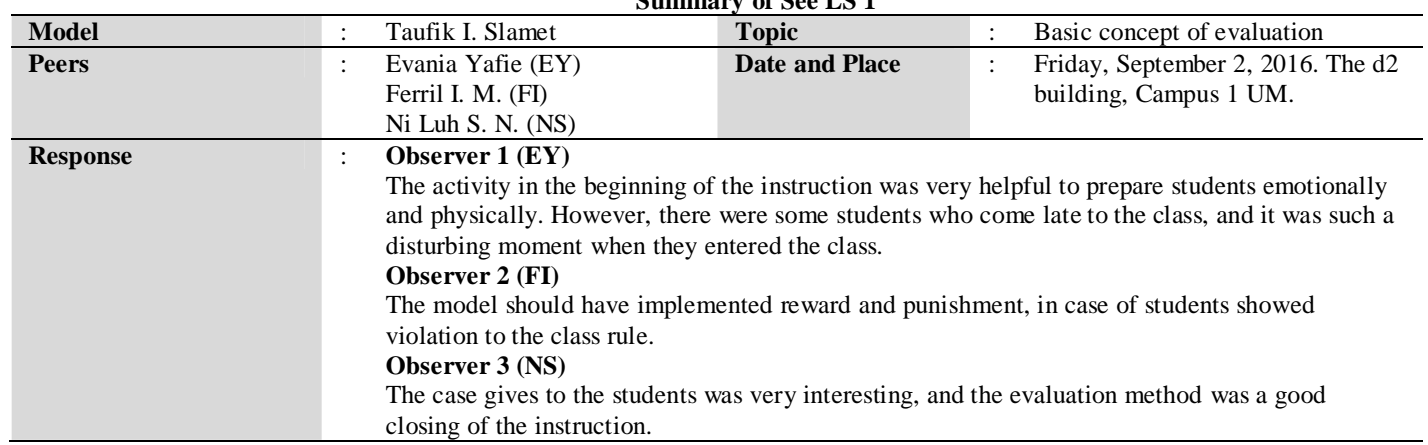

Lesson Study 2 (LS 2)

Table 5

Summary of Plan LS 2

\begin{tabular}{|c|c|c|c|c|}
\hline Model & : & Taufik I. Slamet & Topic & : Taxonomy of learning objectives \\
\hline Peers & : & $\begin{array}{l}\text { Evania Yafie (EY) } \\
\text { Ferril I. M. (FI) } \\
\text { Ni Luh S. N. (NS) }\end{array}$ & Objective & $\begin{array}{l}\text { Identify taxonomy of learning } \\
\text { objectives }\end{array}$ \\
\hline Date and Place & : & $\begin{array}{l}\text { Monday, September 5, } 2016 \text {. } \\
\text { The d2 building, Campus } 1 \\
\text { UM. }\end{array}$ & Model of teaching & : $\quad$ Inquiry learning \\
\hline Suggestion & : & \multicolumn{3}{|c|}{$\begin{array}{l}\text { Observer } 1 \text { (EY) } \\
\text { Inquiry based learning was required an interesting issue to discuss, and it should be formulated in } \\
\text { the form of ill-constructed problem. } \\
\text { Observer } \mathbf{2} \text { (FI) } \\
\text { Reading references should be added into complement materials, either they were textbooks or } \\
\text { journal articles. } \\
\text { Observer } \mathbf{3} \text { (NS) } \\
\text { Visual media was required to be delivered in various form, not only power point slides but also } \\
\text { video or still picture. }\end{array}$} \\
\hline
\end{tabular}

Do

The implementation of the plan 2 was held on September 8, 2016, 37 students participated in this meeting. The inquiry learning consists five general steps of instruction, they were: (1) formulated the problem; (2) developed the hypothesis; (3) examine the tentative answer; (4) formulated the conclusion; and (5) generalized the conclusion. The main topic for this meeting was the taxonomy of learning objectives by Benjamin Bloom (revised), it was delivered by mainly discussion and quiz methods.

\section{See}

Table 6

Summary of See LS 2

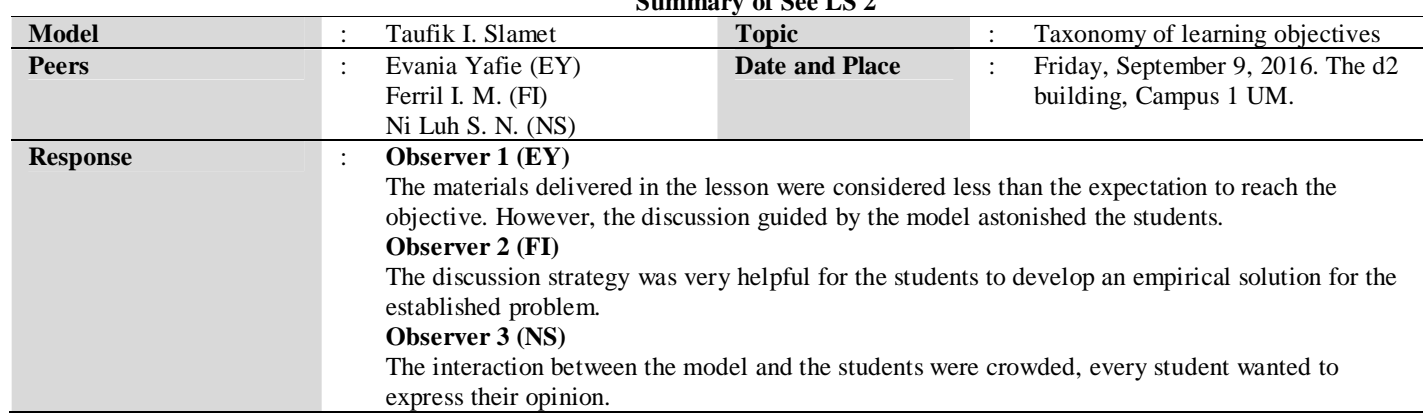


Lesson Study 3 (LS 3)

Table 7

Summary of Plan LS 3

\begin{tabular}{|c|c|c|c|c|}
\hline \\
\hline Model & $:$ & Taufik I. Slamet & Topic & Training needs analysis \\
\hline Peers & : & $\begin{array}{l}\text { Evania Yafie (EY) } \\
\text { Ferril I. M. (FI) } \\
\text { Ni Luh S. N. (NS) }\end{array}$ & Objective & $\begin{array}{ll} & \text { Conduct need assessment in } \\
& \text { learning }\end{array}$ \\
\hline Date and Place & $:$ & $\begin{array}{l}\text { Monday, September 12, } \\
\text { 2016. The e2 building, } \\
\text { Campus } 1 \text { UM. }\end{array}$ & Model of teaching & : $\quad$ Cooperative learning \\
\hline Suggestion & : & \multicolumn{3}{|c|}{$\begin{array}{l}\text { Observer } 1 \text { (EY) } \\
\text { The allocated time was not suitable for the plan. It needed a longer time to reach the objective } \\
\text { through the process. } \\
\text { Observer } 2 \text { (FI) } \\
\text { There should be a moderator to guide the cooperative activities. } \\
\text { Observer } 3 \text { (NS) } \\
\text { The activities were interesting, however, the model should add some topics to enrich students } \\
\text { comprehension. }\end{array}$} \\
\hline
\end{tabular}

Do

In this implementation, 13 postgraduate students from supervisor's class in postgraduate program joined as observers. The topic of the meeting was front end analysis including need analysis and need measurement. The cooperative learning formulated in the plan step was started by dividing class into some work groups, and each group had approximately 6 to 7 students. In the cooperative learning, the issue or problem given to the students was required to be the open-ill constructed problem. The problem needed to be discussed and solved in the group, and there also should be activities which were able to create interaction among the group in the class.

See

Table 8

Summary of See LS 3

\begin{tabular}{|c|c|c|c|c|}
\hline Model & : & Taufik I. Slamet & Topic & Training needs analysis \\
\hline Peers & $:$ & $\begin{array}{l}\text { Evania Yafie (EY) } \\
\text { Ferril I. M. (FI) } \\
\text { Ni Luh S. N. (NS) } \\
\text { Dr. A. Supriyanto (AS) }\end{array}$ & Date and Place & $\begin{array}{l}\text { Thursday, September 15, } 2016 . \\
\text { The d1 building, Campus } 1 \text { UM. }\end{array}$ \\
\hline Response & & \multicolumn{3}{|c|}{$\begin{array}{l}\text { Observer } 1 \text { (EY) } \\
\text { The conclusion of the lesson had not been delivered well, because of the time was not enough to } \\
\text { deliver all the activities. } \\
\text { Observer } 2 \text { (FI) } \\
\text { The discussion gave students the opportunities to discuss in the well mannered. } \\
\text { Observer } 3 \text { (NS) } \\
\text { The process was success because the model gave different problems for each group, so they } \\
\text { could discuss different topics but to solve a similar kind of solution. } \\
\text { Observer } 4 \text { (AS) } \\
\text { The formulated cooperative activities were successful to activate students motivation to discuss } \\
\text { the problem. It was not only success to enrich students knowledge, but also to activate them } \\
\text { physically. }\end{array}$} \\
\hline
\end{tabular}

Lesson Study 4 (LS 4)

Table 9

Summary of Plan LS 4

\begin{tabular}{|c|c|c|c|c|}
\hline Model & : & Taufik I. Slamet & Topic & $\begin{array}{ll}: & \text { Norm and criterion based } \\
\text { evaluation }\end{array}$ \\
\hline Peers & : & $\begin{array}{l}\text { Evania Yafie (EY) } \\
\text { Ferril I. M. (FI) } \\
\text { Ni Luh S. N. (NS) }\end{array}$ & Objective & $\begin{array}{l}\text { Identify norm and criterion based } \\
\text { evaluation }\end{array}$ \\
\hline Date and Place & : & $\begin{array}{l}\text { Monday, September 19, } \\
\text { 2016. The e2 building, } \\
\text { Campus 1 UM. }\end{array}$ & Model of teaching & : $\quad$ Contextual teaching and learning \\
\hline Suggestion & : & \multicolumn{3}{|c|}{$\begin{array}{l}\text { Observer } 1 \text { (EY) } \\
\text { The model should give an explanation about the activities delivered in the meeting, especially } \\
\text { with the contextual learning. } \\
\text { Observer } \mathbf{2} \text { (FI) } \\
\text { There was a long time allocated to deliver the lesson, and the model should adjust the time with a } \\
\text { number of activities. } \\
\text { Observer } 3 \text { (NS) }\end{array}$} \\
\hline
\end{tabular}

Do

The contextual teaching and learning adopted for this phase were started by collecting data from the students. The data, in this case, was the experience from the students about the test which they took along studying in the school. The model discussed what the students felt about the test, and how their teacher ranked them in order. The data discussed in the lesson which describes students experience was a characteristic of contextual teaching and learning. After 
discussing their experiences, the model connected the experiences with the topics and analyzed the components of evaluation and the way their teacher ranked them in order.

See

Table 10

Summary of See LS 4

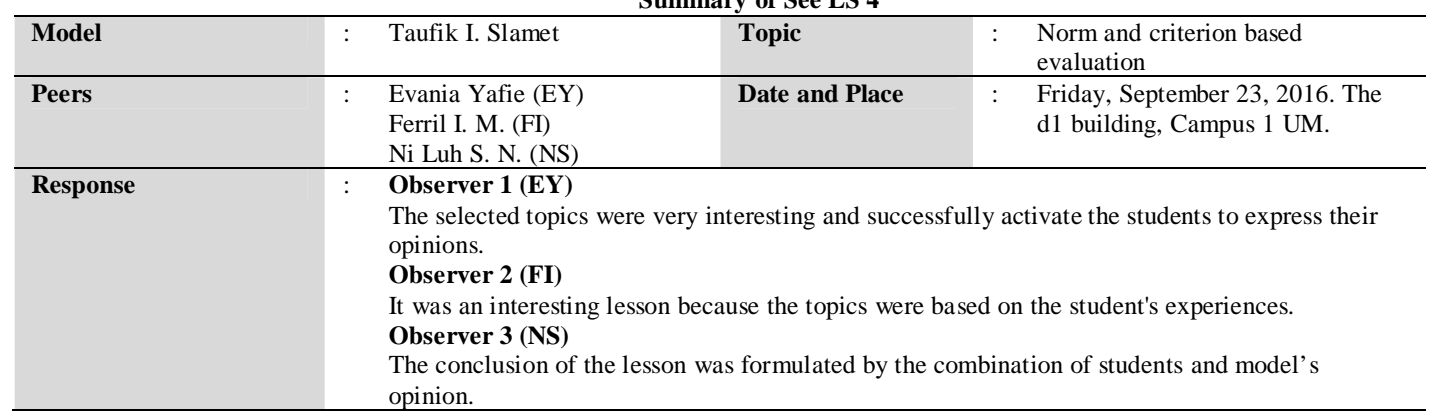

\section{DISCUSSION}

Underpinning the Lesson Study approach is Situated Learning Theory (Lave \& Wenger, 1991), which advances the premise that learning is situated in the specific activity and is embedded within a particular context and culture. Lave and Wenger posited that learning is a social process in which individuals co-construct knowledge rather than transmit knowledge from one individual to the next (Anfara et. al., 2009). The four lesson study activities in the faculty which have been successfully delivered by the group creates an opportunity for the members to learn new knowledge and empirical experiences based on the peer's performances.

The members of lesson study group state that the lesson study leads them to move the approach of learning, from teacher centered to student centered. As like as Japanese mathematics instruction, which has transformed from teacher-directed instruction to childcentered instruction during the past fifteen years (Lewis and Tsuchida 1998; Yoshida 1999). The ability to make this change has widely been attributed to the efforts of lesson study (Takashi \& Yoshida, 2004).

The best challenge of the activities come from the invisible of the effect of the instruction. There are few of evidence about the perception of the students related to the efforts made by the models. Lesson study needs to be measured not only by the objective tests which assess the knowledge change but also it should measure how students perception transforming. Therefore, before the lesson study process begins, it is required to create an instrument that measures every aspect of instruction.

Lesson Study enables teachers to build on their efforts and refine their understandings. In the case reported by Lewis et al. (2009), teachers on their own initiative decided to continue to meet to further revise their lesson to allow colleagues to observe the research lesson and collect data. Lesson study as a professional development program at higher education level in Indonesia has the same foundation of means with the lesson study in another education level. It is focused on the relationship between students outcomes and teachers' teaching strategy that encourage further successful learning for students. However, there is slightly different about lesson study in higher education level based on the profound of the 'teaching lesson' materials. It is very noticeable that not every lecturer has experienced in taking courses about instructional strategy or teaching practices.

Consequently, the teaching lessons should be the main focus of the lesson study and to develop lecturers' idea of different approaches to teaching (Doig \& Groves, 2011), regardless the content to deliver. It is also important to point out that key educational innovations and improvements have been linked to lesson study. For example, Lewis and Tsuchida (1997) have documented the important role to lesson study in transforming the traditional science lessons of the 1950s into today's very prevalent inquiry-based approach to science teaching (Ferandez, 2002). It is very un-doubtful that every lecturer introduced to lesson study through the introduction sections of the training herein has been nervous about teaching in front of other observers and the follow-up discussions that ensue after this public teaching. However, lesson study in higher education level has been a promising project. In fact, there are pockets of fundings that lesson study groups can apply for to support their activities.

The learning and teaching culture in higher education level are seen as the same model of instruction to any other prior levels of education. However, it has a slight difference in the construction of learning environment. In particular, the aim of lesson study is to help lecturers to think about how to encourage rich student questions (Fernandez, 2002). A number of American educators (Lewis \& Tsuchida, 1998; Stigler \& Hiebert, 1999; Yoshida, 1999) have seen great promise in lesson study as a form of professional development that could be adopted in countries around the world, especially in the United States. Since pedagogical training in higher education is a relatively new phenomenon in most countries and it is getting more common around the world (Norton, et. al., 2005).

\section{ACKNOWLEDGEMENT}

We gratefully acknowledge the help of LP3 UM in providing the tremendous efforts for facilitating the whole lesson study cycles, particularly with the basic training of lesson study by the most experienced 
mentors in the State University of Malang (UM). Great thanks are delivered to the faculties in the department of educational technology of State University of Malang, whom with their policies, this lesson study process has been completed in a timely manner. And also, we would like to express our gratefulness to the students who have participated as observers in every phase of the lesson study.

\section{REFERENCES}

[1] Anfara, J, V. A., Lenski, S. J., \& Caskey, M. M. 2009. Using the Lesson Study Approach to Plan for Student Learning. Middle School Journal, 40(3), 50-57.

[2] Bailey, J. G. 1999. Academics' Motivation and Selfefficacy for Teaching and Research. Higher Education Research and Development, 18(3), 343-359.

[3] Fernandez, C. 2002. Learning from Japanese Approaches to Professional Development: The Case of Lesson Study. Journal of teacher education, 53(5), 393-405.

[4] Gibbs, G., \& Coffey, M. 2004. The Impact of Training of University Teachers on Their Teaching Skills, Their Approach to Teaching and the Approach to Learning of Their Students. Active Learning in Higher Education, 5, 87-100.

[5] Lewis, C. C., Perry, R. R., \& Hurd, J. 2009. Improving Mathematics Instruction Through Lesson Study: A Theoretical Model and North American Case. Journal of Mathematics Teacher Education, 12, 285-304. DOI 10.1007/s10857009-9102-7.

[6] Lieberman, A. 1996. Practices that Support Teacher Development: Transforming Conceptions of Professional Learning. In McLaughlin, M. W., \& Oberman, I., (Eds.), Teacher Learning: New Policies, New Practices (p. 185-201). New York: Teachers College Press.

[7] Norton, L., Richardson, J. T. E., Hartley, J., Newstead, S., \& Mayes, J. 2005. Teachers' Beliefs and Intentions Concerning Teaching in Higher Education. New York: Teachers College Press.

[8] Postareff, L., Lindblom-Ylänne, S., \& Nevgi, A. 2007. The Effect of Pedagogical Training on Teaching in Higher Education. Teaching and Teacher Education, 23(5), 557-571.

[9] Takahashi, A., \& Yoshida, M. 2004. Lesson-study Communities. Teaching Children Mathematics, 10(9), 436-437.

[10] Teaching Quality Enhancement Committee (TQEC). 2003. Final Report of the TQEC on the Future Needs and Support for Quality Enhancement of Learning and Teaching in Higher Education. HEFCE/UUK/SCOP (The Cooke Report). Retrieved December 12, 2015, from http://www.hefce.ac.uk/learning/tqec/final.htm.

[11] Trowler, P., \& Bamber, R. 2005. Compulsory Higher Education Teacher Training: Joined-up Policies, Institutional Architectures, and Enhancement Cultures. International Journal for Academic Development, 10(2), 79-93.

[12] Universities UK/SCOP/HEFCE/HEA. 2004. Towards a Framework of Professional Teaching Standards. Retrieved December 12, 2015, from http://www.universitiesuk.ac.uk/consultations/Universit iesUK/downloads/teachingstandards.pdf. 